\title{
Improving passing skills on volleyball using target games approach
}

\author{
Khurotul Aini \\ Universitas Islam 45 Bekasi, Indonesia
}

Received: 16 July 2020; Accepted 06 December 2020; Published 05 January 2021

Ed 2021; 6(1): 22-28

\begin{abstract}
Passing on volleyball is important in volleyball games, but students have difficulty determining the exact passing result with the target. This study improves the passing skills on volleyball in volleyball learning on students of VII A grade in-state junior high school 1 Probolinggo using the target games approach. The research method uses Classroom Action Research. The implementation of this class action is by two cycles. Each cycle consists of 4 stages, namely (1) planning, (2) implementation, (3) observation, and 4) reflection. The subjects of this study are students of VII A grade in State Junior High School 1 Probolinggo. The collecting techniques of the data use observation sheets, documentation, and tests. The results of the passing skills test on volleyball in the first cycle, the number of students amount 30 people, there are 29 students able to do the passing beginning movement on the volleyball correctly $90.25 \%$ with good category, 27 students can do the movements correctly in the subject position of $81.12 \%$ with good category, and 28 students are able to make the final movement correctly $80.25 \%$ with a good category. Based on the results of the study, it can be concluded that learning of passing on volleyball through the target games approach can improve the passing skills on volleyball of students in State Junior High School Probolinggo. It is hoped that in the future, research can be found that develops target games with other types of games to overcome student learning difficulties.
\end{abstract}

Keywords: Passing; physical education; target games

https://doi.org/10.25299/sportarea.2021.vol6(1).5288

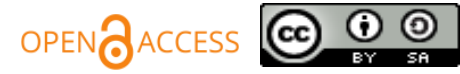

Copyright @ 2021 Khurotul Aini

Corresponding author: Khurotul Aini, Physical Education Health and Recreation, Universitas Islam 45 Bekasi, Bekasi, Jawa Barat, Indonesia

Email: khurotulainiunismabekasi@gmail.com

How To Cite: Aini, K. (2021). Improving passing skills on volleyball using target games approach. Journal Sport Area, 6(1), 2228. https://doi.org/10.25299/sportarea.2021.vol6(1).5288

\section{INTRODUCTION}

Improving the quality of learning through tactical approaches must be carried out continuously so that the goal of improving the quality of learning is achieved. Physical education is a period off from academic lessons carried out in class, but physical education is considered to have the goal of learning and exercising simultaneously so that students stay in good shape (Coulter \& Ní Chróinín, 2013). Through physical education, children and adolescents get health benefits from musculoskeletal and cardiovascular (Slingerland, Haerens, Cardon, \& Borghouts, 2014). The virtue of physical education, in general, is to significantly improve physical activity, memory, and learning outcomes (Herbert \& Whitney, 2018). Besides, another opinion states that the main focus of physical education is to emphasize a series of physical instructions that provide opportunities for students where activities are relevant to students' lives now and in the future (Dyson, 2014). Physical education can be developed well in the school environment. School is an 
environment where children spend most of their time and can be used to promote physical education at school age (Escalante, García-Hermoso, Backx, \& Saavedra, 2014).

Some ways and methods can be done to improve learning outcomes in physical education subjects, both modifications in terms of learning infrastructure, teaching methods, approaches in the learning process, and so on. The teacher's innovation development must pay attention to the age characteristics at each level of education, because the physical education learning design refers to the ability of skills according to the theory of the phases of child development (Mannan \& Sopyan, 2015). Middle school age is a transitional period from the end of childhood to adolescence, so that sometimes the world is still carried away in elementary schools, such as still like the types of games that can be played at any time. The transition from childhood to adolescence is an important period for adopting simple physical activities for the better in the future (Jaakkola \& Washington, 2013). Even physical activity is much associated with the level of health during adolescence (Dudley, Okely, Cotton, Pearson, \& Caputi, 2012).

One of the material deliveries that experienced obstacles when the observation activity was carried out was material passing over. Top passing is one of the basic volleyball techniques where students must know how to pass over effectively (Nur, 2016). The results of the observations showed that the number of students who completed was $55 \%$. As many as $45 \%$ were still below the minimum passing criteria, besides that based on the results of field observations. It was seen that when delivering the material of passing on volleyball the teacher still used the classical method, namely by exemplifying the movement of passing over then the students doing motion tasks according to the instructions from the teacher. When the task of passing the over motion is carried out, the student has not been able to direct the ball according to the target, such as over the net or at a height above the net. Meanwhile, the main objective in carrying out a pass is that the ball bounces at least slightly above the net to make it easier for the ball to be hit or over the net to cross into the opponent's area as a form of attack. So it is important to find solutions to the problems faced by students. Because there are so many basic techniques in volleyball that the teacher needs to convey to students. To convey information, of course, one technique requires the teacher's special skills to be conveyed effectively and efficiently to students. How to improve sports skills must be studied separately to facilitate the maximum transfer of information through playing (Broek, Boen, Claessens, Feys, \& Ceux, 2011).

Combining sport with play is recognized as a method to motivate students and make physical education more enjoyable (Lindberg, Seo, \& Laine, 2016). Playing is the primary methodology for forming intrinsic motivation in students (Lucas, 2017). The results of previous research also state that a physical education teacher must be able to assess important aspects of physical education learning, including assessing student performance in performing motion tasks, tactical decision making, and student participation in a game (Lodewyk \& Bracco, 2013). Playing physical education activities is a form of student participation (Aggerholm, Standal, Barker, \& Larsson, 2018). Belka states the grouping of games into several classifications such as touch games/tag games, target games, net, and wall games, invasion games, and field games (Butler, 2010). Target games are games carried out to reach the target or target that is determined precisely and correctly (Krističević, Madić \& Krakan, 2016). Referring to the problems found during observation, one way out that can be done is the target game approach or target games. This approach is expected to facilitate teaching material to be accepted by students in interesting and easy to be practiced by students.

Physical education suppresses "unique" contributions by focusing on developing the whole physical or physical activity (Coulter \& Ní Chróinín, 2013). One form of contribution in this study is to use the target games approach as a state-of-the-art research. According to student needs, not all teachers carry out upper passing learning but are still oriented towards the value that must be achieved. Students can develop cognitive, affective, and psychomotor skills to carry out basic passing-over techniques through this target games approach. Based on the background that has been described, the problem formulation in this study is how to improve volleyball passing skills with the playing method and how the volleyball passing learning model with a target games approach in class VII A students of SMP Negeri 1 Kota Probolinggo. 


\section{METHODS}

Classroom action research is the accuracy of learning activities in the form of an action, which is deliberately raised and occurs in the classroom together. This research was conducted at SMP Negeri 1 Kota Probolinggo, East Java, from June to December 2019. This study's subjects were students of class VII A of SMP Negeri Probolinggo City with 30 students, 20 boys, and 10 girls. In this study, the physical education teacher of SMP Negeri 1 Kota Probolinggo as the presenter on volleyball passing learning, the researcher as an observer using the observation sheet. The data in this study are quantitative. The research design used by the researcher is a type of classroom action research from Kemmis and Mc. Taggart (Koshy, 2005) who uses a cycle of activities with the following stages: (1) planning (2) action, (3) observing, (4) reflection and revision of action if needed, which is described as follows:

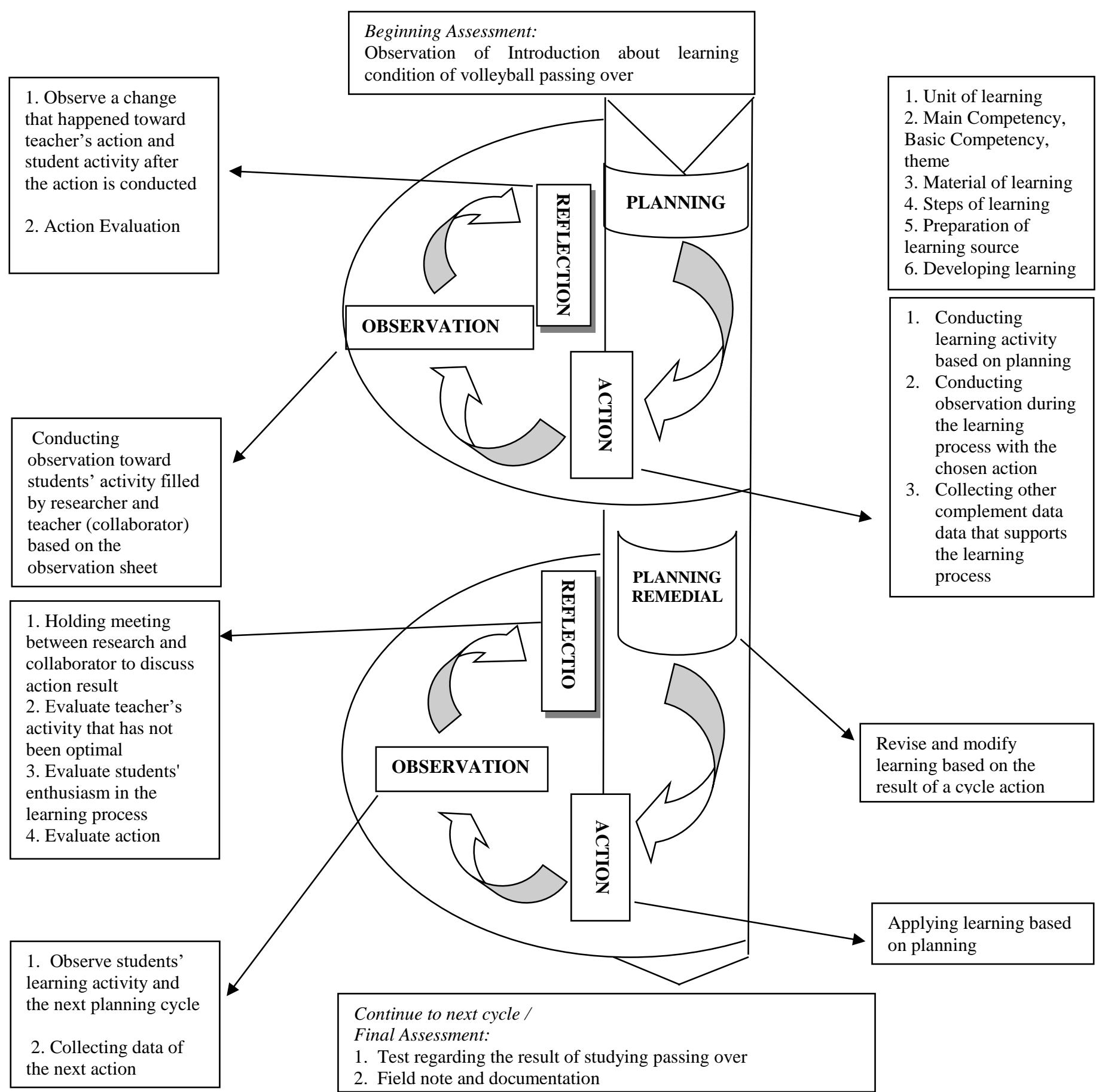

Figure 1. Action Research Design Adapted by Kemmis and Mc Taggart's Model (Sukardi, 2012) 
The researcher gave a value of 1 for the correct movement and a value of 0 for movements that were not in accordance with the correct indicator of the motion during the initial, strike, and final scans attitude. The data analysis technique in this study was used to test and non-test techniques. The test technique is done to find out whether a person's skills have increased or decreased. The types of tests used are oral tests, written tests, and practical tests. At this stage, the researchers used the following French Cooper standard passing tests:

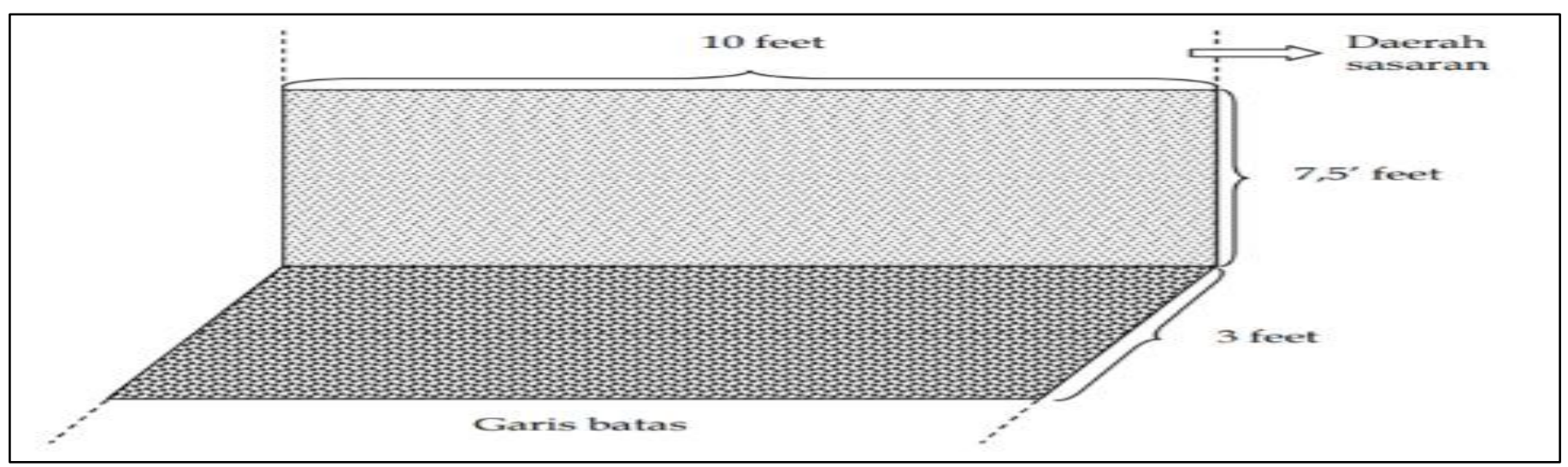

Figure 2.Form and Size of the French-Cooper Repeated Volleyball Test Instrument (Winarno, 2006)

The results are then managed into the percentage of successful passes using the formula:

Volleyball passing success $=\frac{\text { Total Score Obtained }}{\text { Maximum Score }} \mathrm{X} 100 \%$

For the non-test technique, the researcher made direct observations and recorded all the events in the field by using the observation sheet.

\section{RESULT AND DISCUSSION}

The results of this study show that the teacher delivered materials that have been compiled by researchers with variations of target games in volleyball passing learning for class VII A students of SMP Negeri 1 Probolinggo as follows:

1. Variation 1 "Limited Passing."

Purpose: this game helps students do the initial movement, exposure to the final attitude. Rules: students are divided into groups. 1 ball is for 1 pair. The position of students is standing on each boundary box. Execution procedure: When the whistle sounds, the students immediately pass, the first touch of the ball is vertical, while the second touch of the ball is passed to the partner, and so on. When passing students only in the boundary box. This activity is carried out for 30 seconds for each pair.

2. Variation 2 "Dolphin Obstacle."

Objective: To help students get used to the position of passing over and parabolic ball and on target. Rules: Students are divided into groups. Each group carries 1 ball and 1 hose. Children stand on the volleyball court facing each other, $2 \mathrm{~m}$ apart. Procedure for implementation: Students pass over and are directed at the hose. After performing the task of moving is immediately to replace the target actor's position and so on.

3. Variation 3 "Fringed Rope Obstacle."

Purpose: To help students get used to their passing position and on target. Rules: Students are divided into groups, 1 ball for 1 group, and stand facing each other. Execution procedure: This activity is carried out by passing over with $2 \mathrm{x}$ touches in pairs. This activity is carried out for 1 minute for each pair.

In the non-test assessment, the researcher made observations made on May 5, 2019, at SMP N 1 Probolinggo City, the researcher referred to the teacher's lesson plan (RPP). Researchers take notes on 
various strengths, weaknesses, and important events during the process of implementing physical education learning. The following is a description of the results of the 1 st, 2 nd, and 3rd meetings in cycle 1 in table 1.

Table 1. Results of the 1st, 2nd, and 3rd Meetings in Cycle 1

\begin{tabular}{lccc}
\hline Indicator of Correct & \multicolumn{3}{c}{ Cycle 1 } \\
\cline { 2 - 4 } Movement & Meeting 1 & Meeting 2 & Meeting 3 \\
\hline Beginning Posture & $80,5 \%$ & $85,62 \%$ & $90,25 \%$ \\
Approval Position & $60,75 \%$ & $70,37 \%$ & $81,12 \%$ \\
Final Posture & $59,22 \%$ & $63,62 \%$ & $80,25 \%$ \\
\hline
\end{tabular}

Based on the data table 1 shows the results of the increase in volleyball passing skills in class VII A SMP Negeri 1 Probolinggo City at the 1st meeting on the prefix attitude, the percentage was $80.5 \%$, the position was $60.75 \%$, and the final attitude was 59.22. \% . At the second meeting on the prefix attitude, the percentage was $85.62 \%$. The impact position was $70.37 \%$, and the final attitude was $63.62 \%$. And at the 3rd meeting, the prefix attitude obtained a percentage of $90.25 \%$, the position was $81.12 \%$, and the final attitude was $80.25 \%$. So it can be concluded that the completeness value of learning passing over as many as 20 students $(68.29 \%)$ students have reached the minimum completeness limit of 75.00. While 10 students have not completed yet $(31.71 \%)$, which can be seen in table 2 .

Table 2. Completeness Result of Students' Passing Over Studying

\begin{tabular}{ccccc}
\hline No & Completeness & $\begin{array}{c}\text { Standard of Minimum } \\
\text { Completeness }\end{array}$ & F & $\%$ \\
\hline 1. & Complete & $>75,00$ & 20 & $68,29 \%$ \\
2. & Incomplete & $<75,00$ & 10 & $31,71 \%$ \\
\hline & Total & & 30 & 100 \\
\hline
\end{tabular}

The results showed an increase in the learning outcomes of volleyball passing, which can be seen in table 2. It can be seen that the completeness value has increased by $68.29 \%$, and students who do not complete have decreased by $31.71 \%$. The choice of the target games approach is one solution that the teacher can use. This is supported by the results of research, which states to improve game skill, it can include the development of learning methods to produce tactical and technical uses, one of which is using target games (Memmert et al., 2015). In the passing over, the material presented in this study uses a target games approach that can be used to improve the results of passing skills. The results of previous research support this research based on the technique of selecting the type of game that must be adjusted to the goals and needs of physical education learning (Lodewyk \& Bracco, 2013). This is because physical education learning is a means of one's appearance in a game that is used to measure the success of movement (Perlman, Forrest, Pearson, \& Pearson, 2012). Using the target games approach can be used as a measure of the success of children's movement performances in carrying out movement activities. Researchers used these target games to be applied at junior high school to the basic techniques of passing on volleyball.

Target games are classified based on the concept of motion whose purpose is the same, which in essence is to convey learning content through play (Pill, 2016). Other studies also support the use of target games on passing over skills. Through the form of instruction in the form of a game using target, games can increase the focus of the pedagogical process by understanding through game activities (Araújo, Mesquita, Hastie, \& Pereira, 2015). Besides, in other studies, it is stated that through target games it increases intrinsic motivation, perceptions of competence, increase satisfaction, pleasure, and reduces boredom because it involves challenging task preferences that can increase students' physical literacy Morgan (2019) so that the results of these studies support the research conducted by researchers relating to the choice of solutions in solving problems in learning volleyball passing techniques using target games. However, this study's limitations are focused on only one material of passing over, so it is necessary to study the implementation of target games in other basic volleyball techniques. 


\section{CONCLUSION}

Based on the research results that have been done, there was found students' passing over skills using target game was increased. The next researcher hopes that it can be further investigated about other types of game approaches to achieve overall goals, namely cognitive, affective and psychomotor goals for physical education and health at all levels of the teaching unit.

\section{REFERENCES}

Aggerholm, K., Standal, O., Barker, D. M., \& Larsson, H. (2018). On practicing in physical education: outline for a pedagogical model. Physical Education and Sport Pedagogy, 23(2), 197-208. https://doi.org/10.1080/17408989.2017.1372408

Araújo, R., Mesquita, I., Hastie, P., \& Pereira, C. (2015). Students' game performance improvements during a hybrid sports education-step-game-approach volleyball unit. European Physical Education Review, 22(2), 185-200. https://doi.org/10.1177/1356336X15597927

Broek, G. Vande, Boen, F., Claessens, M., Feys, J., \& Ceux, T. (2011). Comparison of three instructional approaches to enhance tactical knowledge in volleyball among university students. Journal of Teaching in Physical Education, 30(4), 375-392. https://doi.org/10.1123/jtpe.30.4.375

Butler, J. I. L. L. G. (2010). More Teaching Games for Understanding Moving Globally. Australia: Human Kinetics.

Coulter, M., \& Ní Chróinín, D. (2013). What is PE? Sport, Education and Society, 18(6), 825-841. https://doi.org/10.1080/13573322.2011.613924

Dudley, D. A., Okely, A. D., Cotton, W. G., Pearson, P., \& Caputi, P. (2012). Physical activity levels and movement skill instruction in secondary school physical education. Journal of Science and Medicine in Sport, 15(3), 231-237. https://doi.org/10.1016/j.jsams.2011.10.005

Dyson, B. (2014). Quality physical education: A commentary on effective physical education teaching. Research Quarterly for Exercise and Sport, 85(2), 144-152. https://doi.org/10.1080/02701367.2014.904155

Escalante, Y., García-Hermoso, A., Backx, K., \& Saavedra, J. M. (2014). Playground Designs to Increase Physical Activity Levels During School Recess: A Systematic Review. Health Education and Behavior, 41(2), 138-144. https://doi.org/10.1177/1090198113490725

Herbert, P. C., \& Whitney, E. A. (2018). Physical Activity Stations: Opportunities for Teachers and Students during the School Day. Strategies, 31(5), 37-41. https://doi.org/10.1080/08924562.2018.1491712

Jaakkola, T., \& Washington, T. (2013). The relationship between fundamental movement skills and selfreported physical activity during Finnish junior high school. Physical Education and Sport Pedagogy, 18(5), 492-505. https://doi.org/10.1080/17408989.2012.690386

Koshy, V. (2005). Action Research for Improving Practice. London: Paul Chapman Publishing.

Lindberg, R., Seo, J., \& Laine, T. H. (2016). Enhancing Physical Education with Exergames and Wearable Technology. IEEE Transactions on Learning Technologies, 9(4), 328-341. https://doi.org/10.1109/TLT.2016.2556671 
Lodewyk, K. R., \& Bracco, E. (2013). Differences in Adaptive Outcomes between Previous Physical Education and a Teaching Games for Understanding Games Unit in Adolescent Girls. Journal of Research PE.

Lucas, F. M. M. (2017). The Game as an Early Childhood Learning Resource for Intercultural Education. Procedia - Social and Behavioral Sciences, 237(June 2016), 908-913. https://doi.org/10.1016/j.sbspro.2017.02.127

M. Nur Mannan, Achmad Sopyan, S. (2015). Pengembangan Perangkat Pembelajaran Berbasis Kearifan Lokal untuk Menembangkan Karakter Positif Siswa SD. Jurnal Inovasi Dan Pembelajaran Fisika, 2(2), 141-146.

Memmert, D., Hillmann, W., Huttermann, S., Klein-Soetebier, T., Konig, S., Nopp, S., ... Griffin, L. (2015). Top 10 research questions related to teaching games for understanding. Research Quarterly for Exercise and Sport, 86(4), 347-359. https://doi.org/10.1080/02701367.2015.1087294

Morgan, K. (2019). Applying the TARGET Pedagogical Principles in Physical Education to Enhance Students' Physical Literacy. Journal of Physical Education, Recreation and Dance, 90(1), 9-14. https://doi.org/10.1080/07303084.2018.1535339

Nur, H. W. (2016). Pengaruh Permainan Target Terhadap Kemampuan Shooting Dalam Permainan Sepakbola Pada Siswa Kelas Khusus Olahraga Di SMA N 2 Playen Gunungkidul. Universitas Negeri Yogyakarta.

Perlman, D., Forrest, G., Pearson, P., \& Pearson, P. (2012). Nintendo Wii: Opportunities to put the Education back into Physical Education. 37(7).1-10.

Pill, S. (2016). An Appreciative Inquiry Exploring Game Sense Teaching In Physical Education. Sport, Education and So, 3322(March). https://doi.org/10.1080/13573322.2014.912624

Slingerland, M., Haerens, L., Cardon, G., \& Borghouts, L. (2014). Differences in perceived competence and physical activity levels during single-gender modified basketball game play in middle school physical education. European Physical Education Review, 20(1), 20-35. https://doi.org/10.1177/1356336X13496000

Sukardi, M. (2012). Metode Penelitian Tindakan. Yogjakarta: Bumi Aksara.

Krističević, T., Madić, D., \& Krakan, I. (2016). Effect of Game-based Conditioning Training on Volleyball Skill Accuracy in Junior Players. Acta Kinesiologica. 10(1), 15-19. https://doi.org/10.1017/CBO9781107415324.004

Winarno, M. E. (2006). Tes Keterampilan Olahraga. Malang: Laboratorium Jurusan Ilmu Keolahragaan FIP UM. 